\title{
Photosymbiotic ascidians from Pari Island (Thousand Islands, Indonesia)
}

\author{
Euichi Hirose', Budhi Hascaryo Iskandar², Yusli Wardiatno ${ }^{3}$ \\ I Department of Chemistry, Biology and Marine Science, Faculty of Science, University of the Ryukyus, Ni- \\ shihara, Okinawa 903-0213, Japan 2 Department of Fishery Resources Utilization, Faculty of Fisheries and \\ Marine Science, Bogor Agricultural University, Gedung FPIK Lt. 3, Kampus IPB Darmaga, Bogor 16680, \\ Indonesia 3 Department of Aquatic Resources Management, Faculty of Fisheries and Marine Science, Bogor \\ Agricultural University, Gedung FPIK Lt. 3, Kampus IPB Darmaga, Bogor 16680, Indonesia \\ Corresponding author: Euichi Hirose (euichi@sci.u-ryukyu.ac.jp)
}

Academic editor: L. Penev | Received 6 March 2014 | Accepted 3 June 2014 | Published 30 June 2014

http://zoobank.org/BE731D31-B812-4546-A7F6-15BC51262158

Citation: Hirose E, Iskandar BH, Wardiatno Y (2014) Photosymbiotic ascidians from Pari Island (Thousand Islands, Indonesia). ZooKeys 422: 1-10. doi: 10.3897/zookeys.422.7431

\begin{abstract}
Photosymbiotic ascidian fauna were surveyed in the subtidal zone off Pari Island in the Thousand Islands (Java Sea, Indonesia). Nine species were recorded: Didemnum molle, Trididemnum miniatum, Lissoclinum patella, L. punctatum, L. timorense, Diplosoma gumavirens, D. simile, D. simileguwa, and D. virens. All of these species have been previously recorded in the Ryukyu Archipelago, Japan. Diplosoma gumavirens and D. simileguwa were originally described from the Ryukyu Archipelago in 2009 and 2005, respectively, and all of the observed species are potentially widely distributed in Indo-West Pacific coral reefs.
\end{abstract}

\section{Keywords}

Algal symbiosis, Colonial ascidian, Biogeography, Coral reefs, Didemnidae

\section{Introduction}

In tropical waters, some colonial ascidians harbor cyanobacterial symbionts such as Prochloron (reviewed by Lewin and Cheng 1989; E. Hirose et al. 2009a; Hirose 2014). 
The host ascidians always belong to the family Didemnidae, which is likely the largest family in the class Ascidiacea (e.g., Kott 2004; Shenkar et al. 2011). Although photosymbiotic didemnids are sometimes more common than any other ascidians in shallow coral reefs, they are often overlooked because of their small size and cryptic habitats. In contrast, they have been attractive sources of bioactive compounds for researchers in the biochemical and pharmaceutical sciences (e.g., Schmidt et al. 2012). To date, about 30 species in the four didemnid genera (Didemnum, Diplosoma, Lissoclinum, and Trididemnum) have been recorded as host species worldwide (e.g., Kott 2001). However, the ranges of distribution of individual species are less understood, as few faunal records of photosymbiotic ascidians exist (e.g., Kott 2001; Monniot and Monniot 2001). To identify these species, it is often necessary to examine zooid morphology under a microscope. Therefore, reexamination may be necessary for some records in older publications.

The Pulau Pari Technical Management Unit for Human Resources Development on Oceanography Competency is a marine laboratory located on Pari Island (Thousand Islands, Indonesia). This laboratory of the Indonesian Institute of Sciences (LIPI) is one of the key stations for marine science in the Java Sea. Therefore, acquiring biodiversity data in this area is essential. Here, we report the photosymbiotic ascidian fauna observed in the shallow coral reef in the vicinity of this laboratory.

\section{Materials and methods}

Samples were collected by snorkeling in the shallow subtidal zone down to approximately $2 \mathrm{~m}$ or less at low tide in the back reef, reef flat, and reef crest off Pari Island (552'S, 106 $\left.36^{\prime} 40 " \mathrm{E}\right)$ on 28-30 November 2013 (Fig. 1). Ascidian colonies were photographed in situ prior to collection. Specimens were anesthetized using menthol and $0.37 \mathrm{M} \mathrm{MgCl}_{2}$ for approximately $2 \mathrm{~h}$ and then fixed with $10 \%$ formalin-seawater. Fixed colonies were dissected under a binocular stereomicroscope. Zooids and spicules were photographed using a microscope equipped with differential interference contrast optics. In some photomicrographs of the thoraxes, several images were combined to increase the depth of field using the post-processing image software Helicon Focus Pro 4.2.8 (Helicon Soft, Ltd., Kharkov, Ukraine). Cyanobacterial symbionts were identified based on the colour in live specimens and the cytomorphology under a light microscope. Ascidian taxa were mainly identified following Kott (2001) and Hirose and $\mathrm{Su}$ (2011). The work by Shenkar et al. (2014) was also consulted for synonyms. Specimens were deposited in the Museum Zoologicum Bogoriense, Research Institute for Biology, Indonesian Institute of Science (LIPI), Indonesia.

\section{Results}

Nine photosymbiotic ascidian species were found in the subtidal zone of the coral reef off Pari Island. Symbiont cyanobacteria within all ascidian species were identified as 

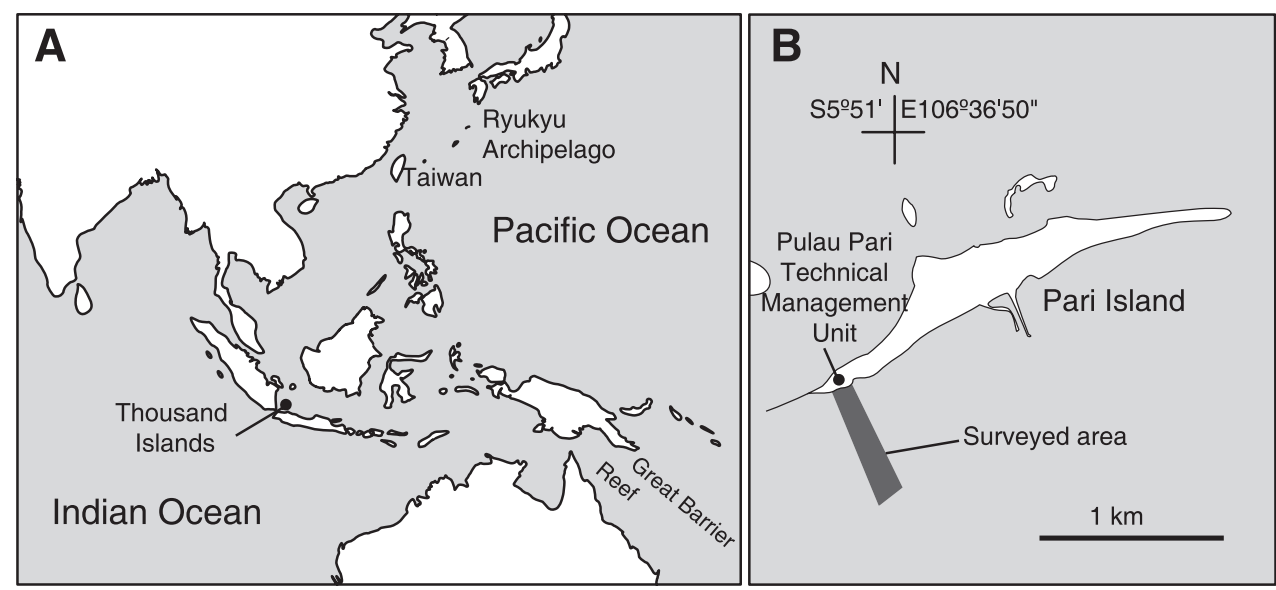

Figure I. Location of Thousand Islands, Indonesia $(\mathbf{A})$ and the surveyed area off Pari Island (B).

Prochloron didemni that is the only taxonomically valid species. Depending on the host species, Prochloron cells were distributed in the common cloacal cavities, in the tunic, or in both the common cloacal cavity and the tunic. Although the Prochloron cells in the cavity are morphologically different from those in the tunic (Cox 1986), they are indistinguishable genetically (Münchhoff et al. 2007; Hirose et al. 2012).

\section{Didemnum molle Herdman, 1886}

Fig. 2A

Diplosomoides molle Herdman, 1886

Leptoclinum molle (Herdman, 1886)

Lissoclinum molle (Herdman, 1886)

Didemnum sycon Michaelsen, 1920

Specimen. MZB. Asc. 00001

Habitat. Coral limestone at reef crest.

Remarks. Colonies were dome-shaped. Several morphotypes in colony shape and color exist in this species (i.e., brown, gray, white, large, and small type). These morphotypes can also be distinguished by the partial sequence of the cytochrome oxidase subunit I (COI) gene (M. Hirose et al. 2009; Hirose et al. 2010a). Brown-type colonies were found in the present survey. Prochloron cells were distributed within the common cloacal cavity. Testis and/or oocyte were found in some zooids.

\section{Trididemnum miniatum Kott, 1977}

Fig. 2B

Specimens. MZB. Asc. 00002

Habitat. Dead coral skeletons and macroalgae in shallow back reef. 

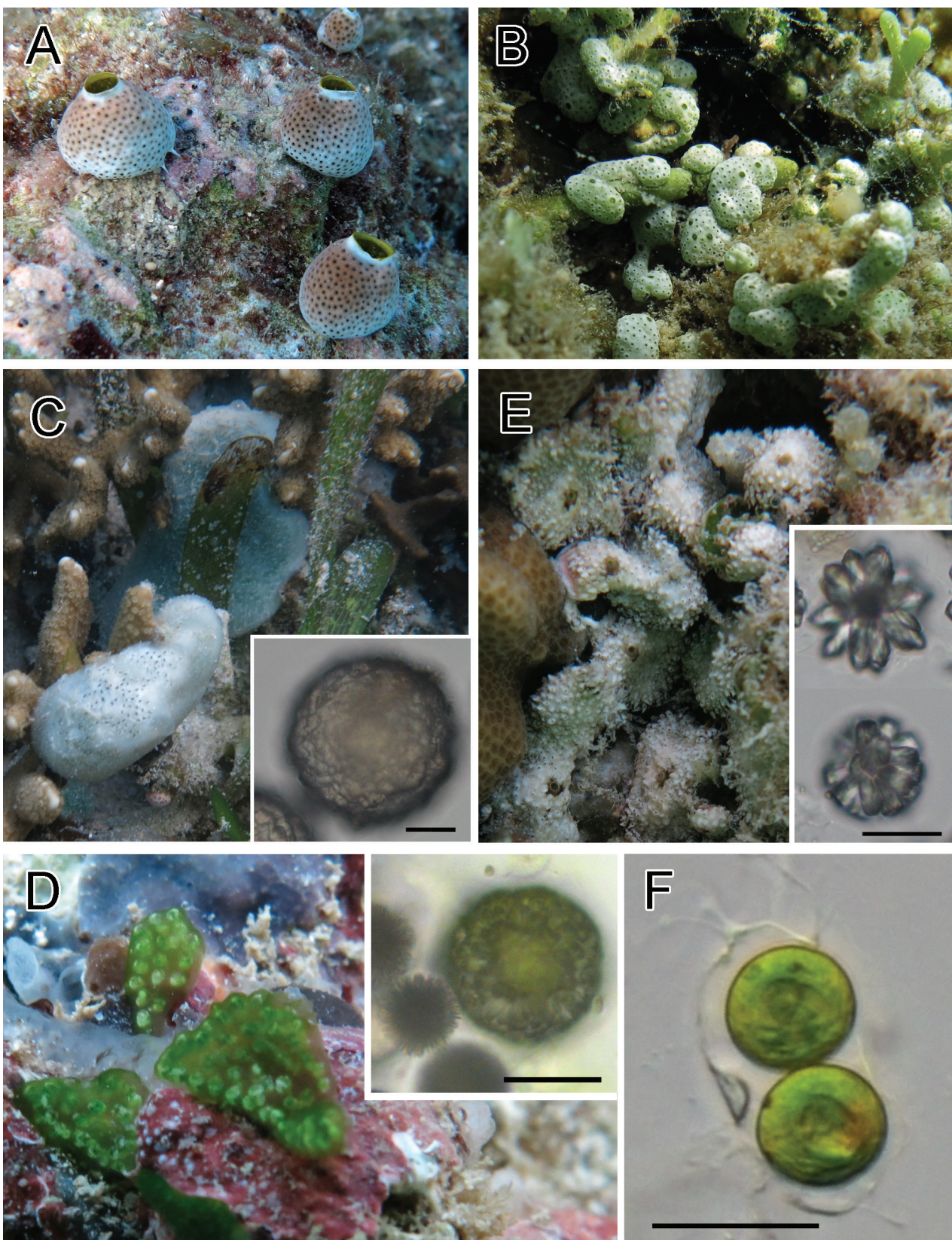

Figure 2. Photosymbiotic ascidians with tunic spicules. Colonies in situ and tunic spicules (inset) of Didemnum molle (A), Trididemnum miniatum (B), Lissoclinum patella (C), L. punctatum (D), and L. timorense (E). Tunic cells contain Prochloron cells in the tunic of L. punctatum (F). Scale bars $=20 \mu \mathrm{m}$.

Remarks. Thin sheets of colonies were white in exposed habitat and pale green in shaded habitat, depending on the amount of calcareous spicules in the tunic. Prochloron cells were distributed within the tunic. 


\section{Lissoclinum patella (Gottschaldt, 1898)}

Fig. 2C

Didemnoides patella Gottschaldt, 1898

Didemnoides sulcatum Gottschaldt, 1898

Didemnoides ternatanum Gottschaldt, 1898

Didemnum meandrium Sluiter, 1909

Didemnum patella (Gottschaldt, 1898)

Didemnum ternatanum (Gottschaldt, 1898)

Leptoclinum patella (Gottschaldt, 1898)

Lissoclinum patellum (Gottschaldt, 1898)

Specimens. MZB. Asc. 00003

Habitat. Dead coral skeletons in back reef.

Remarks. Colonies were thick cushions attaining about $10 \mathrm{~mm}$ in thickness. Tunic contains both stellate and globular spicules (Fig. 1C, inset). Prochloron cells were distributed within the common cloacal cavity. Some zooids had testes. Because of the large size, this species has been thoroughly studied for its natural compounds (e.g., Schmidt et al. 2012).

\section{Lissoclinum punctatum Kott, 1977}

Fig. 2D, F

Specimens. MZB. Asc. 00004

Habitat. Shaded side of dead coral skeletons in reef flat.

Remarks. Colonies were irregularly shaped sheets. Globular spicules (Fig. 1D, inset) form a capsule-like aggregation enveloping each zooid. Prochloron was distributed within the common cloacal cavities and tunic. As reported in Hirose et al. (1996), algal cells in the tunic were contained in the tunic cells of the host ascidian (Fig. 1F).

\section{Lissoclinum timorense (Sluiter, 1909)}

Fig. 2E

Didemnum timorensis Sluiter, 1909

Didemnum voeltzkowi Michaelsen, 1920

Lissoclinum timorensis (Sluiter, 1909)

Lissoclinum voeltzkowi (Michaelsen, 1920)

Specimens. MZB. Asc. 00005

Habitat. Dead coral skeletons and clefts between coral limestones in back reef and shallow reef flat. 
Remarks. Colonies had linguiform projections of the tunic around the colony periphery and sometimes on the colony surface. Tunic contains both stellate and globular spicules (Fig. 1E, inset). Prochloron cells were distributed within the common cloacal cavity.

Because the zooids of Lissoclinum bistratum and L. timorense are very similar in morphology, Monniot and Monniot (2001) proposed that L. timorense is a junior synonym of $L$. bistratum. Typical colonies of the two species are easily distinguishable by the presence or absence of linguiform projections on the colony surfaces, although intermediate forms between the two exist. Kott (2001) discriminated the two species based on the presence or absence of stellate spicules. However, the two species defined by spicule type could not be discriminated by molecular phylogeny based on partial COI gene sequences (Hirose et al. 2010b). We did not find L. bistratum-type colonies in the present survey, although they are common in reef crests of the Ryukyus.

\section{Diplosoma gumavirens Hirose \& Oka, 2009}

Fig. 3A, B

Specimens. MZB. Asc. 00006

Habitat. Shaded side of dead coral branches in reef flat.

Remarks. Colonies were oval cushions and entirely green due to Prochloron cells distributed within the common cloacal cavities. A blue ring of structural color encircled each branchial siphon. Retractor muscle emerged from halfway along esophageal neck of a zooid. On each of the right and left halves of the branchial sac, there were five stigmata in the first (top), second, and third stigmatal rows and four stigmata in the fourth row (bottom). Here, we describe the pattern of stigma number as 5-5-5-4. This record is the first of this species from outside of the Taiwan-Ryukyu area.

\section{Diplosoma simile (Sluiter, 1909)}

Fig. 3C, D

Diplosoma midori (Tokioka, 1954)

Leptoclinum midori Tokioka, 1954

Leptoclinum simile Sluiter, 1909

Specimens. MZB. Asc. 00007

Habitat. Dead coral branch and coral limestone in reef flat and reef crest.

Remarks. Colonies were irregularly shaped sheets and entirely green due to Prochloron cells distributed within the common cloacal cavities. Retractor muscle emerged from underside of thorax. The numbers of stigmata were 6-6-6-5. Some zooids had testes. Embryos were brooded in some colonies. 


\section{Diplosoma simileguwa Oka \& Hirose, 2005}

Fig. 3E, F

Specimens. MZB. Asc. 00008

Habitat. Shaded side of dead coral branches in reef flat

Remarks. Colonies were irregularly shaped sheets and entirely green due to Prochloron cells distributed within common cloacal cavities. Retractor muscle emerged from underside of thorax. The numbers of stigmata were 4-5-4-3. This record is the first of this species from outside of the Taiwan-Ryukyu area.

\section{Diplosoma virens (Hartmeyer, 1909)}

Fig. 3G, H

Diplosoma viride Herdman, 1906

Leptoclinum calificiforme Sluiter, 1909

Leptoclinum varium Sluiter, 1909

Leptoclinum virens Hartmeyer, 1909

Specimens. MZB. Asc. 00009

Habitat. Basal parts on branching corals in back reef and reef flat.

Remarks. Colonies were irregularly shaped sheets and entirely green due to Prochloron cells distributed within common cloacal cavities. Retractor muscle emerged from halfway along esophageal neck. The numbers of stigmata were 6-6-6-5. Some zooids had testes.

\section{Discussion}

All photosymbiotic ascidians described here have also been recorded in the Ryukyu Archipelago, Japan (Hirose 2013 and references therein). Among the nine species, D. simileguwa and D. gumavirens were originally described from the Ryukyus in 2005 and 2009, respectively (Oka et al. 2005; E. Hirose et al. 2009b), and this report is the first to record these species outside of the Taiwan-Ryukyu area. The present records significantly expand our understanding of their range of distribution. The other seven species have also been described from the Great Barrier Reef (Kott 2001); thus, these species are widely distributed in the Indo-West Pacific. Among the five photosymbiotic ascidians recorded from Singapore, i.e., Diplosoma simile, Lissoclinum bistratum, L. punctatum, L. timorense and Trididemnum cyclops, (Su et al. 2013), two species, L. bistratum and T. cyclops were not recorded in the present survey. These species are likely distributed in the Java Sea, considering that they are commonly found in West Pacific coral reefs. The recognition and identification of species are often important in field 

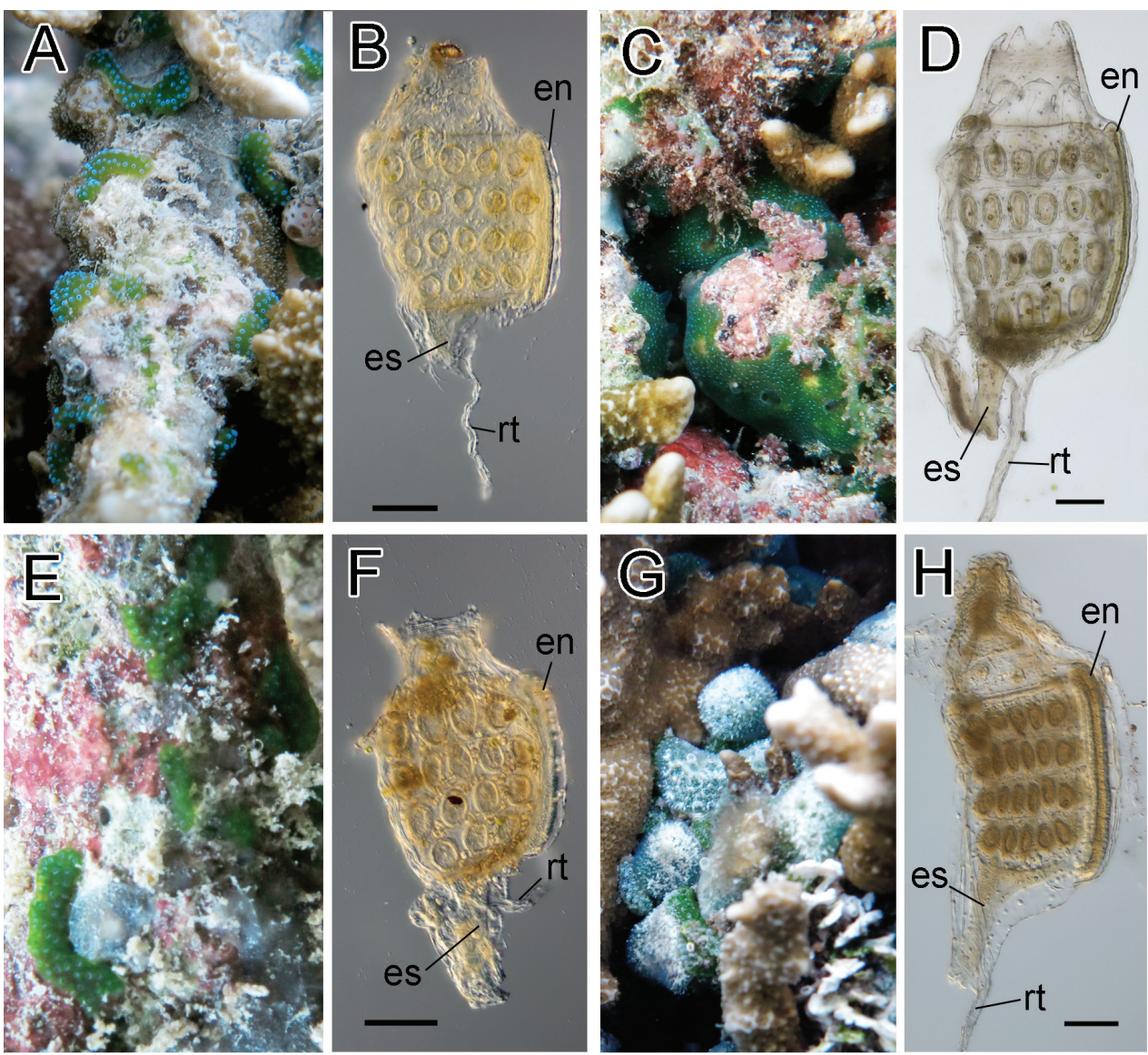

Figure 3. Photosymbiotic ascidians without tunic spicules (Diplosoma species). Colonies in situ and thorax of zooid of Diplosoma gumavirens $(\mathbf{A}, \mathbf{B})$, D. simile $(\mathbf{C}, \mathbf{D})$, D. simileguwa $(\mathbf{E}, \mathbf{F})$, and D. virens $(\mathbf{G}, \mathbf{H})$. en endostyle; es esophagus; $\mathbf{r t}$ retractor muscle. Scale bars $=0.1 \mathrm{~mm}$.

studies dealing with biocoenosis, and we hope that the present report will be helpful in future surveys and field courses in this area. Additional species, including undescribed species, are potentially distributed around Pari Island, considering its location within a biodiversity hot spot. Therefore, additional extensive surveys are necessary to characterize the photosymbiotic ascidian fauna in this area.

\section{Acknowledgments}

We thank Ms. Shelly Nur Ekayanti Tutupoho and Mr. Wahyu Muzammil (Bogor Agricultural University) for their kind help during the field survey. The present study was supported by the International Research Hub Project for Climate Change and Coral Reef/Island Dynamics from University of the Ryukyus. 


\section{References}

Cox GC (1986) Comparison of Prochloron from different hosts 1. Structural and ultrastructural characteristics. New Phytologist 104:429-445. doi: 10.1111/j.1469-8137.1986. tb02910.x

Hirose E (2013) Didemnid ascidians harboring cyanobacteria from Kumejima Island and Tonakijima Island, Ryukyu Archipelago, Japan. Biological Magazine Okinawa 51: 41-49.

Hirose E (2014) Ascidian photosymbiosis: Diversity of cyanobacterial transmission during embryogenesis. Genesis (published online). doi: 10.1002/dvg.22778

Hirose E, Su SW (2011) A new record of a photosymbiotic ascidian from Kenting, Taiwan with a key to the photosymbiotic species of the genus Diplosoma recorded in the western Pacific. Collection and Research 24: 83-86. http://www.nmns.edu.tw/php/Library/ research/201103-83.pdf

Hirose E, Maruyama T, Cheng L, Lewin RA (1996) Intracellular symbiosis of a photosynthetic prokaryote, Prochloron sp., in a colonial ascidian. Invertebrate Biology 115: 343-348. doi: $10.2307 / 3227023$

Hirose E, Neilan B, Schmidt E, Murakami A (2009a) Enigmatic life and evolution of Prochloron and related cyanobacteria inhabiting colonial ascidians. In: Gault P, Marler H (Eds) Handbook on Cyanobacteria. Nova Science Publishers, Inc., New York, 161-189.

Hirose E, Oka AT, Hirose M (2009b) Two new species of photosymbiotic ascidians of the genus Diplosoma from the Ryukyu Archipelago with partial sequences of the COI gene. Zoological Science 26: 362-368. doi: 10.2108/zsj.26.362

Hirose M, Yokobori S, Hirose E (2009) Potential speciation of morphotypes in the photosymbiotic ascidian Didemnum molle in the Ryukyu Archipelago, Japan. Coral Reefs 28: 119-126. doi: 10.1007/s00338-008-0425-0

Hirose M, Nozawa Y, Hirose E (2010a) Genetic isolation among morphotypes in the photosymbiotic didemnid Didemnum molle (Ascidiacea, Tunicata) from the Ryukyus and Taiwan. Zoological Science 27: 959-964. doi: 10.2108/zsj.27.959

Hirose M, Tochikubo T, Hirose E (2010b) Taxonomic significance of tunic spicules in photosymbiotic ascidians: a quantitative and molecular evaluation. Journal of the Marine Biological Association of the United Kingdom 90: 1065-1071. doi: 10.1017/s0025315409991263

Hirose E, Turon X, Lopez-Legentil S, Erwin PM, Hirose M (2012) First records of didemnid ascidians harbouring Prochloron from Caribbean Panama: Genetic relationships between Caribbean and Pacific photosymbionts and host ascidians. Systematics and Biodiversity 10: 435-445. doi: 10.1080/14772000.2012.735716

Kott P (2001) The Australian Ascidiacea part 4, Aplousobranchia (3), Didemnidae. Memoirs of the Queensland Museum 47: 1-408.

Kott P (2004) New and little-known species of Didemnidae (Ascidiacea, Tunicata) from Australia (part 2). Journal of Natural History 38: 2455-2526. doi: 10.1080/00222930310001647334

Lewin RA, Cheng L (1989) Prochloron, a microbial enigma. Chapman \& Hall, New York. doi: 10.1007/978-1-4613-0853-9

Monniot F, Monniot C (2001) Ascidians from the tropical western Pacific. Zoosystema 23: 201-383. 
Münchhoff J, Hirose E, Maruyama T, Sunairi M, Burns BP, Neilan BA (2007) Host specificity and phylogeography of the prochlorophyte Prochloron sp., an obligate symbiont in didemnid ascidians. Environmental Microbiology 9: 890-899. doi: 10.1111/j.14622920.2006.01209.x

Oka AT, Suetsugu M, Hirose E (2005) Two new species of Diplosoma (Ascidiacea: Didemnidae) bearing prokaryotic algae Prochloron from Okinawajima (Ryukyu Archipelago, Japan). Zoological Science 22: 367-374. doi: 10.2108/zsj.22.367

Schmidt EW, Donia MS, McIntosh JA, Fricke WF, Ravel J (2012) Origin and variation of tunicate secondary metabolites. Journal of Natural Products 75: 295-304. doi: 10.1021/ np200665k

Shenkar N, Swalla BJ (2011) Global diversity of Ascidiacea. PLoS ONE 6: e20657. doi: 10.1371/journal.pone.0020657

Shenkar N, Gittenberger A, Lambert G, Rius M, Moreira Da Rocha R, Swalla BJ, Turron X (2014) Ascidiacea World Database. http://www.marinespecies.org/ascidiacea [accessed on 2014-02-17]

Su SW, Hirose E, Chen SL, Mok MH (2013) Photosymbiotic ascidians in Singapore: turbid waters may reduce living space. ZooKeys 305: 55-65. doi: 10.3897/zookeys.305.4893 